\title{
Characterization of the receptor binding residues of kisspeptins by positional scanning using peptide photoaffinity probes.
}

\section{$\operatorname{AUTHOR}(S)$ :}

Misu, Ryosuke; Oishi, Shinya; Setsuda, Shohei; Noguchi, Taro; Kaneda, Masato; Ohno, Hiroaki; Evans, Barry; Navenot, Jean-Marc; Peiper, Stephen C; Fujii, Nobutaka

\section{CITATION:}

Misu, Ryosuke ...[et al]. Characterization of the receptor binding residues of kisspeptins by positional scanning using peptide photoaffinity probes.. Bioorganic \& medicinal chemistry letters 2013, 23(9): 2628-2631

\section{ISSUE DATE:}

2013-05

URL:

http://hdl.handle.net/2433/173793

\section{RIGHT:}

(C) 2013 Elsevier Ltd.; This is not the published version. Please cite only the published version.; この論文は出版社版でありません。引用の際に は出版社版をご確認ご利用ください。 
Characterization of the receptor binding residues of kisspeptins by positional scanning using peptide photoaffinity probes

Ryosuke Misu, ${ }^{\mathrm{a}}$ Shinya Oishi, ${ }^{\mathrm{a} *}$ Shohei Setsuda, ${ }^{\mathrm{a}}$ Taro Noguchi, ${ }^{\mathrm{a}}$ Masato Kaneda, ${ }^{\mathrm{a}}$ Hiroaki Ohno, ${ }^{\mathrm{a}}$ Barry Evans, ${ }^{\mathrm{b}}$ Jean-Marc Navenot, ${ }^{\mathrm{b}}$ Stephen C. Peiper, ${ }^{\mathrm{b}}$ and Nobutaka Fujii ${ }^{\mathrm{a}, *}$

${ }^{a}$ Graduate School of Pharmaceutical Sciences, Kyoto University, Sakyo-ku, Kyoto 606-8501, Japan

${ }^{\mathrm{b}}$ Department of Pathology, Anatomy and Cell Biology, Thomas Jefferson University, Philadelphia, PA 19107, USA

*Corresponding Authors:

Shinya Oishi, Ph.D. and Nobutaka Fujii, Ph.D.

Graduate School of Pharmaceutical Sciences

Kyoto University

Sakyo-ku, Kyoto, 606-8501, Japan

Tel: +81-75-753-4551; Fax: +81-75-753-4570,

E-mail (S.O.): soishi@pharm.kyoto-u.ac.jp; E-mail (N.F.): nfujii@pharm.kyoto-u.ac.jp 


\begin{abstract}
Kisspeptins, endogenous peptide ligands for GPR54, play an important role in GnRH secretion. Since in vivo administration of kisspeptins induces increased plasma LH levels, GPR54 agonists hold promise as therapeutic agents for the treatment of hormonal secretion diseases. To facilitate the design of novel potent GPR54 ligands, residues in kisspeptins that involve in the interaction with GPR54 were investigated by kisspeptin-based photoaffinity probes. Herein, we report the design and synthesis of novel kisspeptin-based photoaffinity probes, and the application to crosslinking experiments for GPR54-expressing cells.
\end{abstract}

Keywords: GPCR, GPR54, Kp-54, Kp-14, photoaffinity probe

Abbreviations: GPR54, G-protein coupled receptor 54; Kp-54, kisspeptin-54; Kp-14, kisspeptin-14, Kp-13, kisspeptin-13, Kp-10, kisspeptin-10; GnRH, gonadotropin-releasing hormone; NPFFRs, neuropeptide FF receptors; PEG, polyethylene glycol; Fmoc-SPPS, Fmoc-based solid phase peptide synthesis; HRP, horseradish peroxidase. 
Kisspeptins, proteolytic products of the propeptide encoded by the Kiss1 gene, have been identified as an endogenous ligand of $G$ protein-coupled receptor 54 (GPR54). ${ }^{1-5}$ Full-length 54-residue kisspeptin (Kp-54) and endogenous short peptides [kisspeptin-14 (Kp-14) and kisspeptin-13 (Kp-13)] share the C-terminal consensus sequence of the RF-amide peptide family, -Arg-Phe- $\mathrm{NH}_{2}{ }^{1}$ The kisspeptin-GPR54 signaling complex plays a vital role in gonadotropin secretion via stimulation of gonadotropin-releasing hormone $(\mathrm{GnRH})$ release. ${ }^{6-16}$ The in vivo administration of kisspeptins and derivatives with potent GPR54 agonistic activity induces an increase in the plasma LH level. ${ }^{17,18}$ Thus, GPR54 agonists are expected to be potential pharmaceutical agents for disorders of hormone secretion.

In 2001, Ohtaki et al. reported that the C-terminal 10-residue peptide [kisspeptin-10 (Kp-10)] was the minimal bioactive sequence of kisspeptins. Although $\mathrm{Kp}-10$ has been reported to exert antimetastatic effects via GPR54 activation, ${ }^{4,19} \mathrm{Kp}-10$ was found to be rapid degraded in serum. ${ }^{20}$ Recently, several biostable Kp-10 analogs have been developed. ${ }^{20-23}$ For example, TAK-488 with good peptidase resistance retains highly potent GPR54 agonistic activity that is comparable to Kp-10. ${ }^{22}$ We have also identified a pentapeptide-based GPR54 agonist, FTM080, through down-sizing studies of Kp-10. ${ }^{24,25}$ Further structure-activity relationship studies of FTM080 using a series of peptidomimetics identified FTM145 with high biological stabilities. ${ }^{26}$

These previous studies demonstrated the requirement for the C-terminal region of kisspeptins in direct receptor binding and activation of GPR54. However, for the design of more potent GPR54 ligands, elucidation of the contact residues in kisspeptins and the recognition modes for GPR54 are required. A positional scanning approach of kisspeptin-based photoaffinity probes was used to identify residues that interact with GPR54. Reported herein is the development and application of novel photoaffinity probes derived from two endogenous kisspeptins, Kp-54 and Kp-14. 
Initially, we designed Kp-54-based probes that contain a photoreactive group to form a covalent bond onto GPR54 and a biotin tag to detect labeled GPR54. ${ }^{27-29}$ Since the C-terminal region of kisspeptins is required for binding to GPR54, ${ }^{4,24-26}$ the biotin group was conjugated at the N-terminus of Kp-54. A panel of ligands was created with the photoreactive functional group conjugated to the Cys thiol group at the N-terminal Ser ${ }^{5}, \mathrm{Ser}^{10}, \mathrm{Gln}^{15}, \mathrm{Ser}^{20}, \mathrm{Arg}^{25}, \mathrm{Pro}^{30}$, $\mathrm{Leu}^{35}$, or Lys $^{40}$ locations with Cys replacements (designated S5C, S10C, Q15C, S20C, R25C, P30C, L35C, or K40C, respectively) (Fig. 1). Each residue in the C-terminal sequence, $\mathrm{Tyr}^{45}-\mathrm{Leu}^{52}$, was also modified with the photoreactive group (designated Y45C, N46C, W47C, N48C, S49C, F50C, G51C, and L52C). All the probes retained the indispensable C-terminal RF-amide substructure $\left(-\mathrm{Arg}^{53}-\mathrm{Phe}^{54}-\mathrm{NH}_{2}\right)$.

Peptide chains of Kp-54 derivatives were constructed by standard Fmoc-based solid-phase peptide synthesis (Fmoc-SPPS) on Novasyn ${ }^{\circledR}$ TGR resin. The amino acid at the modification site for a photoreactive functional group was substituted with a Cys residue. The N-terminal biotin was attached by the standard coupling protocol. After final deprotection and cleavage from the resin, the photoreactive group-conjugated maleimide $\mathbf{1}$ was attached onto the Cys thiol group in the biotinylated Kp-54 peptides. RP-HPLC purification afforded the expected Kp-54 peptides, which were identified with ESI-MS (Table S1).

Using this panel of Kp-54-based probes, the crosslinking experiment was carried out for HEK293 cells stably expressing GPR54. After incubation with the probes, the cells were exposed to UV light through a $300 \mathrm{~nm}$ long pass filter for $30 \mathrm{~s}$. The cell lysates were separated by SDS-PAGE and the biotin on the kisspeptin crosslinked to GPR54 was subsequently detected by probing Western blots with horseradish peroxidase (HRP)-conjugated streptavidin. When using six probes (P30C, L35C, K40C, Y45C, N46C and W47C), a 65-kDa band was detected (Fig. 2A). In the competitive binding experiments of these six probes in the presence of unlabeled Kp-10, this 65-kDa band completely 
disappeared (Fig. 2B), indicating the specific detection of GPR54. Of note, the probes with modification at the N-terminus (S5C, S10C, Q15C, S20C or R25C) did not form a covalent crosslink to GPR54, presumably because these residues are not located in sufficiently close proximity to directly interact with the receptor. In addition, when using the probes with modification at a C-terminal residue (N48C, S49C, F50C, G51C or L52C), crosslinks to GPR54 were not observed. This is consistent with the findings from our previous alanine scanning experiments of Kp-10, in which substitution of these residues resulted in significant reductions in the agonistic activity. ${ }^{25}$ The modification of these residues with a photoaffinity functional group may interfere with crucial interactions necessary for binding to GPR54. Taken together, we have identified six Kp-54-based photoaffinity probes with modification of residues upstream of the C-terminal necessary residues for GPR54 binding, suggesting that this region (Pro30-Trp47) in Kp-54 may contribute to the secondary site(s) for binding to GPR54.

We next used this approach for the development of photoaffinity probes using Kp-14. On the basis of the structure-activity relationships obtained by the Kp-54-based probe studies, we designed three photoaffinity probes with an N-terminal biotin and a photoreactive group at $\mathrm{Tyr}^{5}$, $\operatorname{Asn}^{6}$ or $\operatorname{Trp}^{7}$ in Kp-14 (Fig. 1). These modified residues correspond to $\operatorname{Tyr}^{45}, \mathrm{Asn}^{46}$ and $\operatorname{Trp}^{47}$ in $\mathrm{Kp}-54$, which were successfully modified with the photoreactive group in the functional Kp-54-based probes. However, contrary to our expectation, no labeling of GPR54 was observed using these probes (Fig. 3A). We assumed that streptavidin binding to the probes in the Western blot analysis was inhibited because the biotin tag was attached directly to the bioactive Kp-14 sequence without any linker. ${ }^{30}$

To avoid the possible reduced accessibility of streptavidin, three probes with a polyethylene glycol (PEG) 27 linker between biotin and the Kp-14 sequence (Y5C, N6C and W7C) were designed and synthesized. Among these pegylated Kp-14-based probes, crosslinking of W7C to GPR54 was observed by Western blot analysis using HRP-conjugated streptavidin (Fig. 3A). The binding 
specificity of these Kp-14-derived probes for GPR54 was also confirmed by a competitive binding experiment with unlabeled Kp-10 (Fig. 3B).

Hormonal secretions are regulated by multiple interactions between a number of neuropeptides/peptide hormones and receptors. Recently, we and others reported that short kisspeptin peptides such as Kp-14 and Kp-10 activate two neuropeptide FF receptors (NPFFRs: NPFFR1/GPR147 and NPFFR2/GPR74), ${ }^{31,32}$ which possibly function(s) as negative regulator(s) of GnRH secretion. ${ }^{33-35}$ Although the roles in reproductive physiology for the kisspeptin-NPFFR pairs have not been clearly defined, Kp-54 and the proteolytically processed short peptides may contribute to some physiological functions including GnRH release from the median eminence via an unknown interaction network(s). ${ }^{36-39}$ These Kp-14-based probes would be useful for the photoaffinity labeling experiments to identify previously unrecognized target(s) of kisspeptins. ${ }^{27-29}$

It has been reported that the GPR54 protein (42.5 kDa) contains three N-linked glycosylation sites within the N-terminal region. ${ }^{3}$ To further rationalize the identification of GPR54 using Kp-54- and Kp-14-based photoaffinity probes, deglycosylation experiments of the crosslinked $65 \mathrm{kDa}$ protein were carried out. After UV light exposure in the presence of W47C or W7C (500 nM) for photocrosslinking, the cell lysates were subjected to deglycosylation treatment using peptide N-glycosidase (PNGase F). SDS-PAGE separation followed by Western blot analysis demonstrated that the $65 \mathrm{kDa}$ band was shifted to a mass indicative of a protein that had undergone removal of N-linked oligosaccharide chains (Fig. 4). This observation provides further evidence that the labeled protein with the probes was GPR54.

In conclusion, we have designed and synthesized photoaffinity probes based on two endogenous kisspeptin sequences (Kp-54 and Kp-14). Six Kp-54-based probes (P30C, L35C, K40C, Y45C, N46C and W47C) and one Kp-14-based probe (W7C) clearly detected GPR54 on living cells in a specific manner, suggesting these residues constitute the secondary interactive sites of Kp-54 and 
Kp-14 for receptor binding to GPR54. These probes should be promising tools to identify the distributions of possible kisspeptin receptors, including GPR54.

\section{Acknowledgements}

This work was supported by Grants-in-Aid for Scientific Research and Platform for Drug Discovery, Informatics, and Structural Life Science from the Ministry of Education, Culture, Sports, Science, and Technology of Japan; and Research Program on Innovative Technologies for Animal Breeding, Reproduction, and Vaccine Development (REP-2003) from the Ministry of Agriculture, Forestry and Fisheries of Japan. R.M. is grateful for Research Fellowships from the JSPS for Young Scientists.

\section{Supplementary data}

Supplementary data associated with this article can be found, in the online version, at http://dx.doi.org/10.1016/j.bmcl.2013.02.098. 


\section{References and Footnotes}

1. Kotani, M.; Detheux, M.; Vandenbogaerde, A.; Communi, D.; Vanderwinden, J.-M.; Le Poul, E.; Brézillon, S.; Tyldesley, R.; Suarez-Huerta, N.; Vandeput, F.; Blanpain, C.; Schiffmann, S. N.; Vassart, G.; Parmentier, M. J. Biol. Chem. 2001, 276, 34631.

2. Muir, A. I.; Chamberlain, L.; Elshourbagy, N. A.; Michalovich, D.; Moore, D. J.; Calamari, A.; Szekeres, P. G.; Sarau, H. M.; Chambers, J. K.; Murdock, P.; Steplewski, K.; Shabon, U.; Miller, J. E.; Middleton, S. E.; Darker, J. G.; Larminie, C. G. C.; Wilson, S.; Bergsma, D. J.; Emson, P.; Faull, R.; Philpott, K. L.; Harrison, D. C. J. Biol. Chem. 2001, 276, 28969.

3. Lee, D. K.; Nguyen, T.; O'Neill, G. P.; Cheng, R.; Liu, Y.; Howard, A. D.; Coulombe, N.; Tan, C. P.; Tang-Nguyen, A.-T.; George, S. R.; O'Dowd, B. F. FEBS Lett. 1999, 446, 103.

4. Ohtaki, T.; Shintani, Y.; Honda, S.; Matsumoto, H.; Hori, A.; Kanehashi, K.; Terao, Y.; Kumano, S.; Takatsu, Y.; Masuda, Y.; Ishibashi, Y.; Watanabe, T.; Asada, M.; Yamada, T.; Suenaga, M.; Kitada, C.; Usuki, S.; Kurokawa, T.; Onda, H.; Nishimura, O.; Fujino, M. Nature 2001, 411, 613.

5. $\quad$ Clements, M. K.; McDonald, T. P.; Wang, R.; Xie, G.; O'Dowd, B. F.; George, S. R.; Austin, C. P.; Liu, Q. Biochem. Biophys. Res. Commun. 2001, 284, 1189.

6. De Roux, N.; Genin, E.; Carel, J.-C.; Matsuda, F.; Chaussain, J.-L.; Milgrom, E. Proc. Natl. Acad. Sci. U. S. A. 2003, 100, 10972.

7. Seminara, S. B.; Messager, S.; Chatzidaki, E. E.; Thresher, R. R.; Acierno Jr., J. S.; Shagoury, J. K.; Bo-Abbas, Y.; Kuohung, W.; Schwinof, K. M.; Hendrick, A. G.; Zahn, D.; Dixon, J.; Kaiser, U. B.; Slaugenhaupt, S. A.; Gusella, J. F.; O'Rahilly, S.; Carlton, M. B. L.; Crowley Jr., W. F.; Aparicio, S. A. J. R.; Colledge, W. H. N. Engl. J. Med. 2003, 349, 1614.

8. $\quad$ Funes, S.; Hedrick, J. A.; Vassileva, G.; Markowitz, L.; Abbondanzo, S.; Golovko, A.; Yang, S.; Monsma, F. J.; Gustafson, E. L. Biochem. Biophys. Res. Commun. 2003, 312, 1357. 
9. Gottsch, M. L.; Cunningham, M. J.; Smith, J. T.; Popa, S. M.; Acohido, B. V.; Crowley, W. F.; Seminara, S.; Clifton, D. K.; Steiner, R. A. Endocrinology 2004, 145, 4073.

10. Matsui, H.; Takatsu, Y.; Kumano, S.; Matsumoto, H.; Ohtaki, T. Biochem. Biophys. Res. Commun. 2004, 320, 383.

11. Irwig, M. S.; Fraley, G. S.; Smith, J. T.; Acohido, B. V.; Popa, S. M.; Cunningham, M. J.; Gottsch, M. L.; Clifton, D. K.; Steiner, R. A. Neuroendocrinology 2004, 80, 264.

12. Shahab, M.; Mastronardi, C.; Seminara, S. B.; Crowley, W. F.; Ojeda, S. R.; Plant, T. M. Proc. Natl. Acad. Sci. U. S. A. 2005, 102, 2129.

13. Franceschini, I.; Lomet, D.; Cateau, M.; Delsol, G.; Tillet, Y.; Caraty, A. Neurosci. Lett. 2006, 401, 225.

14. Oakley, A. E.; Clifton, D. K.; Steiner, R. A. Endocr. Rev. 2009, 30, 713.

15. Ohkura, S.; Uenoyama, Y.; Yamada, S.; Homma, T.; Takase, K.; Inoue, N.; Maeda, K.-I.; Tsukamura, H. Peptides 2009, 30, 49.

16. Tomikawa, J.; Homma, T.; Tajima, S.; Shibata, T.; Inamoto, Y.; Takase, K.; Inoue, N.; Ohkura, S.; Uenoyama, Y.; Maeda, K.; Tsukamura, H. Biol. Reprod. 2010, 82, 313.

17. Kinsey-Jones, J. S.; Li, X. F.; Luckman, S. M.; O’Byrne, K. T. Endocrinology 2008, 149, 1004.

18. Ohkura, S.; Takase, K.; Matsuyama, S.; Mogi, K.; Ichimaru, T.; Wakabayashi, Y.; Uenoyama, Y.; Mori, Y.; Steiner, R. A.; Tsukamura, H.; Maeda, K.-I.; Okamura, H. J. Neuroendocrinol. 2009, 21, 813.

19. Lee, J. H.; Miele, M. E.; Hicks, D. J.; Phillips, K. K.; Trent, J. M.; Weissman, B. E.; Welch, D. R. J. Natl. Cancer Inst. 1996, 88, 1731.

20. Asami, T.; Nishizawa, N.; Ishibashi, Y.; Nishibori, K.; Horikoshi, Y.; Matsumoto, H.; Ohtaki, T.; Kitada, C. Bioorg. Med. Chem. Lett. 2012, 22, 6328. 
21. Asami, T.; Nishizawa, N.; Ishibashi, Y.; Nishibori, K.; Nakayama, M.; Horikoshi, Y.; Matsumoto, S.; Yamaguchi, M.; Matsumoto, H.; Tarui, N.; Ohtaki, T.; Kitada, C. Bioorg. Med. Chem. Lett. 2012, 22, 6391.

22. Kitada, C.; Asami, T.; Nishizawa, N. U. S. Patent 7,625,869, 2006.

23. Asami, T.; Nishizawa, N. U. S. Patent 7,960,348, 2007.

24. Niida, A.; Wang, Z.; Tomita, K.; Oishi, S.; Tamamura, H.; Otaka, A.; Navenot, J.; Broach, J. R.; Peiper, S. C.; Fujii, N. Bioorg. Med. Chem. Lett. 2006, 16, 134.

25. Tomita, K.; Niida, A.; Oishi, S.; Ohno, H.; Cluzeau, J.; Navenot, J.; Wang, Z.; Peiper, S. C.; Fujii, N. Bioorg. Med. Chem. 2006, 14, 7595.

26. Tomita, K.; Oishi, S.; Ohno, H.; Peiper, S. C.; Fujii, N. J. Med. Chem. 2008, 51, 7645.

27. Fleming, S. A. Tetrahedron 1995, 51, 12479.

28. Brunner, J. Annu. Rev. Biochem. 1993, 62, 483.

29. Sadakane, Y.; Hatanaka, Y. Anal. Sci. 2006, 22, 209.

30. It cannot be ruled out that the N-terminal biotin tag in the probes prevented the receptor binding itself.

31. Lyubimov, Y.; Engstrom, M.; Wurster, S.; Savola, J.-M.; Korpi, E. R.; Panula, P. Neuroscience 2010, 170, 117.

32. Oishi, S.; Misu, R.; Tomita, K.; Setsuda, S.; Masuda, R.; Ohno, H.; Naniwa, Y.; Ieda, N.; Inoue, N.; Ohkura, S.; Uenoyama, Y.; Tsukamura, H.; Maeda, K.-I.; Hirasawa, A.; Tsujimoto, G.; Fujii, N. ACS Med. Chem. Lett. 2011, 2, 53.

33. Hinuma, S.; Shintani, Y.; Fukusumi, S.; Iijima, N.; Matsumoto, Y.; Hosoya, M.; Fujii, R.; Watanabe, T.; Kikuchi, K.; Terao, Y.; Yano, T.; Yamamoto, T.; Kawamata, Y.; Habata, Y.; Asada, M.; Kitada, C.; Kurokawa, T.; Onda, H.; Nishimura, O.; Tanaka, M.; Ibata, Y.; Fujino, M. Nat. Cell Biol. 2000, 2, 703. 
34. Engström, M.; Brandt, A.; Wurster, S.; Savola, J.; Panula, P. J. Pharmacol. Exp. Ther. 2003, 305, 825.

35. Rizwan, M. Z.; Poling, M. C.; Corr, M.; Cornes, P. A.; Augustine, R. A.; Quennell, J. H.; Kauffman, A. S.; Anderson, G. M. Endocrinology 2012, 153, 3770.

36. Grossman, A.; Clement-Jones, V. Clin. Endocrinol. Metab. 1983, 12, 31.

37. Balasubramaniam, A. Peptides 1997, 18, 445.

38. Branchek, T. A.; Smith, K. E.; Gerald, C.; Walker, M. W. Trends Pharmacol. Sci. 2000, 21, 109.

39. Harrison, S.; Geppetti, P. Int. J. Biochem. Cell B. 2001, 33, 555. 


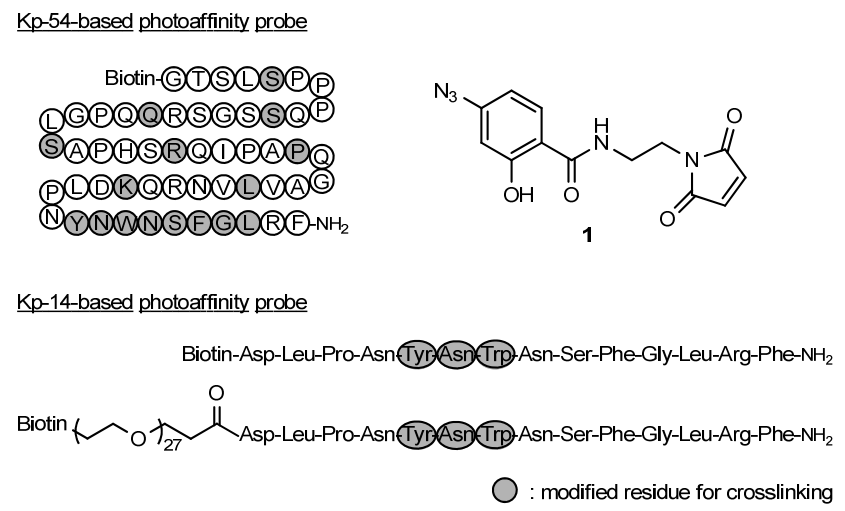

Figure 1. Design of Kp-54- and Kp-14-based photoaffinity probes for GPR54 and the structure of photoaffinity reagent 1.

(A)

$66.2 \mathrm{kDa}-$

$\leftarrow$ GPR54

$42 \mathrm{kDa}$ -

$\leftarrow \beta$-actin

(B)

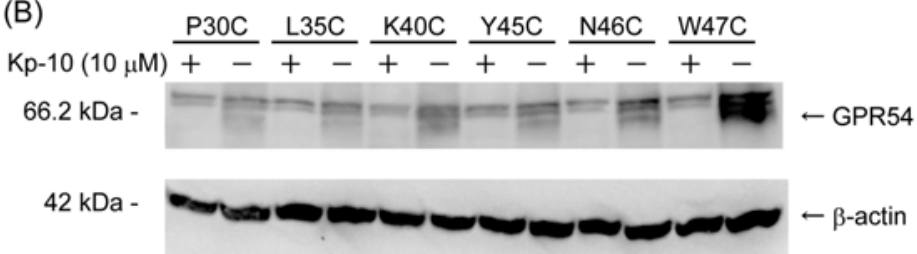

Figure 2. Photocrosslinking experiment of GPR54 with Kp-54-based probes. (A) GPR54-expressing HEK293 cells were incubated with Kp-54-based photoaffinity probes, followed by UV irradiation. Biotin on the crosslinked GPR54 was detected by Western blot analysis. (B) GPR54-expressing HEK293 cells were exposed to a potential Kp-54-based probe (P30C, L35C, K40C, Y45C, N46C and W47C; $500 \mathrm{nM})$ in the presence $(+)$ or absence $(-)$ of unlabeled Kp-10 (10 $\mu \mathrm{M})$ for the competitive experiments. 


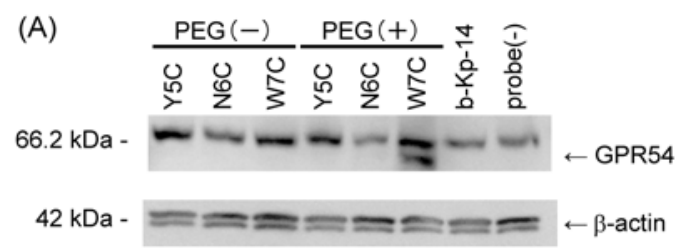

(B)

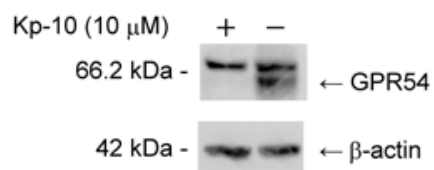

Figure 3. Photocrosslinking experiments of GPR54 with Kp-14-based probes. (A) GPR54-expressing HEK293 cells were labeled by Kp-14-based probes. Biotin on the crosslinked GPR54 was detected by Western blot analysis. (B) GPR54-expressing HEK293 cells were exposed to W7C $(500 \mathrm{nM})$ in the presence $(+)$ or absence $(-)$ of unlabeled Kp-10 $(10 \mu \mathrm{M})$ for the competitive experiments.

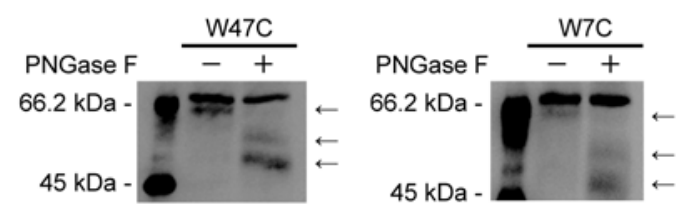

Figure 4. Deglycosylation experiments of labeled GPR54 by W47C (left) and W7C (right). After photocrosslinking, the cell lysate was incubated in the presence $(+)$ or absence $(-)$ of PNGase F. Biotin on the crosslinked GPR54 was detected by Western blot analysis. 